\title{
Apple powdery mildew caused by Podosphaera leucotricha: some aspects of disease management
}

\author{
Holb, I.J. \\ University of Debrecen, P.O. Box 36, H-4015 Debrecen, Hungary (e-mail: holb@agr.unideb.hu)
}

\begin{abstract}
Summary: Apple powdery mildew (Podoshphaera leucorticha) occurs wherever apples are grown. One of the most important fungal disease of apple which causing severe econimic loss on susceptible apple cultivars. This review focuses on the control of apple powdery mildew. The first part of the study provides details of novel aspects of non-chemical control approaches, including agronomic measures, mechanical and biological control options as well as essential features of apple cultivar resistance. After this, developments in chemical control options are described sperately for integrated and organic apple orchards.
\end{abstract}

Keywords: Podosphaera leucotricha, pruning, biological control, host resisitance, chemical control, integrated, organic apple orchard

\section{Introduction}

Apple powdery mildew (Podoshphaera leucorticha) is a wordwide known fungal pathogen of apple. A key important fungal disease of apple which causing severe econimic loss on susceptible cultivars in every years where apple are grown (Hickey and Yoder, 1990; Holb, 2013). Control of the pathogen is widely investigated all over the world in the past 100 years. Thousands of publications were aimed to investigate the possibilities of control and to improve powdery mildew forecasting and disease management. The management of powdery mildew of apple and pear requires consideration of cultivar susceptibility, the desired market quality of the fruit, and the importance of other diseases to be controlled. The reduction of primary inoculum and the protection of leaves, fruit and buds from secondary infections are important. Timely application of effective fungicides is widely used to prevent new infections and reduce the number of spores produced on new lesions. (Hickey and Yoder, 1990). The aim of this review was to prepare a summary for control of apple powdery mildew including agronomic measures, mechanical, biological control and chemical control options in integrated and organic apple orchards.

\section{Features of nonchemical control approaches}

Non-chemical control options include indirect (orchard management practices) and direct (e.g. physical and biological) control measures. In this section, recent developments in non-chemical control options are listed and then their efficacy is evaluated on apple powdery mildew.

\section{Orchard management practices}

Orchard management practices in apple production include several options (e.g. cropping system, planting, pruning, orchard floor management, nutrition supply and harvest) that affect fungal disease management. Orchard management practices are applied in order to provide the best conditions for tree growth as well as to improve yield and fruit quality. This indicates that orchard management has more general aims than just to protect the crop from fungal diseases.

\section{Mechanical control}

Mechanical methods of control of apple diseases aim to reduce or eliminate inoculum sources and to suppress disease spread. Mechanical control can be achieved by several means including pruning of infected plant parts; removal, shredding, burying, and burning of inoculum sources located in above ground parts. Firstly, treatments should be applied to less severely infected fields first, followed by more severely infected ones; secondly, treatments should not be made in wet foliage; thirdly, all used equipment should be cleaned of soil, debris, and disinfected; and fourthly, all removed plant material and crop debris need to be removed from the orchard and destroyed, or if it is not possible then cut into as small pieces as possible and ploughed into the soil as deep as possible (Palti, 1981).

Pruning of apple trees enables direct management of several fungal diseases of apple by the removal of diseased shoots, fruit, stems or dead wood that can harbour pathogens. Dormant season pruning was shown to reduce primary inoculum of apple powdery mildew as the fungus mycelium 
overwinters in buds (e.g. Csorba, 1962; Yoder and Hickey, 1983; Hickey and Yoder, 1990; Holb, 2005). Removal of infected terminal shoots during winter pruning is a generally recommended control practice which enhances the efficacy of chemical control measures (Hickey and Yoder, 1990). In Central Europe, removal of mildew infected terminals reduced primary mildew incidence from 60 to $13 \%$ on the highly mildewsusceptible cultivar 'Jonathan' (Csorba, 1962). In the United States, research revealed that the removal of powdery mildew primary inoculum may be valuable and economically feasible in orchards with moderate to low numbers of primary infections per tree and might lead to less need for fungicides (Yoder and Hickey, 1983; Hickey and Yoder, 1990). A recent study in integrated and organic apple orchards showed that dormant pruning had no significant effect on primary mildew incidence on slightly susceptible cultivars such as 'Gala', 'Rewena' and 'Liberty'. However, primary mildew incidence was significantly lower on moderately susceptible cultivars 'Elstar', 'Pilot' and 'Jonica' but the severity of pruning did not cause significant differences in mildew incidence (Holb, 2005).

\section{Biological control}

Although field application of biological control agents has received great attention, there are only a few commercially applied biological control products against fungal diseases of apple. There are several reasons which do not allow the widespread use of biological control but the two major ones are, firstly, biological products against phylloplane pathogens reduce diseases rather than completely control them and, secondly, market potential of commercialised bioproducts is lower compared with that of conventional fungicides (Andrews, 1990, 1992).

Antagonists: Pycnidial fungi belonging to the genus Ampelomyces are the most common natural antagonists of powdery mildews worldwide (Sztejnberg et al., 1989). On apple trees, Ampelomyces mycoparasites overwintered as resting hyphae in the dried powdery mildew mycelia covering the shoots and in the parasitised ascomata of P. leucotricha on the bark and the scales of the buds. Although commercialised products of Ampelomyces mycoparasites are available against powdery mildew species, there is low practical potential for effective biological control of apple powdery mildew by products prepared from Ampelomyces mycoparasites (Sztejnberg et al., 1989).

Extracts and oils of plants: Extracts and oils of plants are widely recommended by IFOAM standards for organic fruit growers (Anonymous, 2000). These materials are considered as alternative fungicides against fungal diseases of apple in organic growing.

The plant extract of Hedera helix has been shown to reduce incidence of powdery mildew (Bosshard, 1992). Treatments of the extract showed consistently lower mildew incidence than untreated control plots (Bosshard, 1992) but no commercialised product of $H$. helix is currently available.

Northover and Schneider (1993, 1996) tested the prophylactic and therapeutic activity of three low-linoleic acid oils (sunflower, olive, and canola) and three highlinoleic acid oils (corn, soybean, and grapeseed) against powdery mildew. All six oils were equally effective against P. leucotricha, providing $99 \%$ control of the disease. The control efficacy against $P$. leucotricha was comparable to that of dinocap treatments. The six oils in ten applications at 6- to 10-day intervals also decreased scab incidence of fruit and leaf by 81 and 66\%, respectively.

\section{Host resistance}

In most apple growing regions, a lower level of powdery mildew resistance is more acceptable for a cultivar than that of apple scab resistance. This is due to the fact that low mildew susceptibility of cultivars can already be sufficient to avoid fungicide use. The most known oligogenic resistance sources of mildew are M. robusta and M. zummi carrying the Pl1 and Pl2 resistance genes (Knight and Alston, 1968). $\mathrm{Pl} 1$ and $\mathrm{Pl} 2$ genes have been introgressed into advanced selections and new cultivars (Alston, 1983; Schmidt, 1994; White and Bus, 1999). Other major genes, such as Pl-w and Pl-d, are in advanced stages of back-cross programmes and genetic markers are being developed (e.g. Evans and James, 2003; James et al., 2005). However, there is a risk of races developing in the pathogen that overcome single gene resistances, as was experienced with the Pl-m gene from 'Mildew Immune Seedling' (Korban and Dayton, 1983; Lespinasse, 1983) and recently the Pl2 gene (Caffier and Laurens, 2005; Caffier and Parisi, 2007). There was a suggestion that the $\mathrm{Pl}-\mathrm{w}$ from 'White Angel' may have been overcome by a race of the pathogen, too, as all progenies from this cultivar became infected by the end of one season (Lespinasse, 1989). However, absence of the putative races in both cases in the following season suggests that infection may have been the result of high disease pressure. Present resistance-breeding programs against powdery mildew focus on multiple resistance of genotypes including other fungal diseases of apple (e.g. Laurens, 1999; Fischer and Fischer, 1999).

Apple cultivars have been continuously tested for mildew susceptibility in the past century and cvs. 'Jonathan', 'Baldwin', 'Cortland', 'Idared', 'Jonagold', 'Rome Beauty', 'Monroe', 'Gravenstein', 'Stayman Winesap', 'Cox's Orange Pippin', 'Granny Smith', 'Ginger Gold', and 'Prima' were considered to be moderately to highly susceptible. Less susceptible cultivars include 'Delicious', 'Golden Delicious', 'Winesap', 'York Imperial', 'Nittany' and 'Lord Lambourne' (e.g. Aldwinckle 1974; Norton 1981; Scheer 1989; Hickey and Yoder, 1990; Yoder, 2000). Washington et al. (1998) showed that a number of important commercial cultivars are highly susceptible to powdery mildew ('New Jonagold', 23 $\%$; 'Pink Lady', $18 \%$ ); however, there were cultivars with high or moderate levels of resistance to powdery mildew ('Earlidel', no infection observed; 'Red Fuji', 'HiEarly' and 'Redfree', average incidence of mildew between 3 and 6\%). Recently Sholberg et al. (2001) developed a technique for better evaluation of apple cultivars for susceptibility to 
powdery mildew. Authors grafted the selected cultivars to branches of mature 'Jonagold' trees and then evaluated the cultivars in the summer of the same year and in subsequent years after growth on the host tree. The method provided more reliable assessment of powdery mildew resistance than previous assessment methods.

\section{Features of chemical control}

\section{Integrated apple orchards}

The management of apple powdery mildew is partly based on cultivar resistance in integrated orchards (e.g. Yoder and Hickey, 1983; Hickey and Yoder, 1990). Bower et al. (1995) demonstrated that mildew resistant cultivars could reduce effectively the need for mildewicides in apple production. Recently, the use of mildew susceptible cultivars in apple production has decreased; and therefore, powdery mildew control is usually coupled successfully with apple scab management as most of the scab fungicides also sufficiently control powdery mildew. Therefore, separate fungicide sprays are not usual against apple powdery mildew.

Fungicides registered for mildew control are sulphur, oxythioquinox, benzimidazoles, bupirimate, nitrothalisopropy, pyrazophos and EBIs in most countries (e.g. Spotts and Cervantes, 1986; Hickey and Yoder, 1990; Sholberg and Haag, 1994). The primary mildewicides are DMIs and sulphur in apple orchards (Yoder, 2000). The DMIs have been perceived by many growers as being highly effective, but more expensive than sulphur for mildew control (Yoder, 2000). OoI fungicides were also shown to be highly effective in controlling apple powdery mildew (Reuveni, 2000). Trifloxystrobin (at a concentration of $0.01-0.015 \%$ ) was superior to most demethylation inhibitors such as penconazole and myclobutanil (Reuveni, 2000). Highly effective mildewicides, such as most DMIs and OoIs, which strongly suppress the disease, provide acceptable control, even on highly susceptible apple cultivars (Sholberg and Haag, 1994; Reuveni, 2000; Yoder, 2000). However, different levels of DMI and strobilurin resistance in apple powdery mildew isolates were detected (e.g. Reuveni et al., 1998; Reuveni, 2000; Lesemann et al., 2006).

The fungus survives the winter in buds, making it difficult to control during the early spring development of apple trees. First sprays against powdery mildew can only be effective after bud burst when budscales open and overwintered mildew mycelia become available for fungicides. A special action threshold level at 20\% leaf infection was suggested in the Mid-Atlantic region of the USA (Yoder and Hickey, 1995; Yoder, 2000). Applications of fungicides should be made from the tight-cluster stage until terminal shoot growth ceases in midsummer. The interval between sprays is generally 7 days during the stages of rapid leaf development before petal fall and 12-14 days during the post-bloom period. Disease assessment and forecasting systems, which have been successful in western Europe, along with sprays of DMIs before mildew becomes severe, should be highly effective in minimising losses in commercial orchards (Hickey and Yoder, 1990).

Recent research on control of apple powdery mildew tested spray machines, developed integrated fungicidefertilizer spray programmes and improved disease warning. A study of Cross and Berrie (1995) compared axial fan sprayer with the air assisted tunnel sprayer in integrated apple orchards. Authors concluded that control of mildew was similar when using either sprayer. Approximately $30 \%$ of the spray volume applied was collected for recycling with the tunnel sprayer but the main limitations of the tunnel sprayer were its slow maximum forward speed and the restricted tree size and shape on which it can be used. Other research focused on integrating sprays of mono-potassium phosphate (MPH) fertilizer with systemic fungicides against powdery mildew (Reuveni et al., 1998). Reuveni et al. (1998) showed that the effectiveness of alternating systemic fungicides with a $1 \%$ solution of MPH was similar to that of the commercial treatment with the systemic fungicides. In addition, the tank-mix of $1 \% \mathrm{MPH}$ solution with a half rate of fungicides was as effective or superior to that obtained by the standard fungicide treatment. The authors concluded that the inhibitory effectiveness of MPH fertilizer makes it a potential major component of an integrated pest management programme and the MPH fertilizer can also be useful in mildew resistance management. Recent research made also a great development in forecasting apple powdery mildew. Xu (1999) developed a model to simulate epidemics of powdery mildew on vegetative shoots which generates two types of output: i) forecasts of disease severity and ii) indices of the relative favourability of weather conditions on disease development. This model became part of the PC-based disease warning system, Adem(TM). Field evaluation of Adem(TM) resulted in similar or better mildew control than a routine programme (Berrie and $\mathrm{Xu}$, 2003). In addition, Xu and Madden (2002) argued that the leaf incidence-density relationships for apple powdery mildew may also be incorporated into practical disease management decisions.

\section{Organic apple orchards}

In organic apple production, mildew resistance of cultivars is a key element of powdery mildew control. The most commonly used fungicide against powdery mildew in organic apple production is elemental sulphur. Of the mildewicides, sulphur was shown to be the least effective but it was demonstrated that increasing the number of sulphur applications from six to eight increased mildew control and yield (Yoder, 2000). Sulphur sprays are also used against apple scab in organic production; and therefore, the interval between sulphur sprays is generally seven days during both the primary and secondary infection periods of powdery mildew. This frequent use of sulphur compounds against powdery mildew fulfils the marketing requirements for organic apple production. 
In the last two decades, plant and minerals oils also received attention for control of powdery mildew in order to replace the frequent use of sulphur (e.g. Northover and Schneider, 1993, 1996; Grove and Boal, 1996; Yoder et al., 2002; Fernandez et al., 2006). Sunflower, olive, canola, corn, soybean and grapeseed oils were equally effective in providing over $99 \%$ control of P. leucotricha when applied to apple foliage one day before or one day after inoculation (Northover and Schneider, 1993, 1996). The authors also showed that mechanically emulsified canola oil was comparable to dinocap when applied 1, 2, 4, and 7 days after inoculation. Recently, mineral oils were also tested in a three-spray early-season programme targeting apple powdery mildew but the results showed that powdery mildew shoot infestation was suppressed only in one year and no differences in fruit damage were found when treatments were compared to untreated control (Fernandez et al., 2006).

\section{Acknowledgements}

This research was supported partly by a grant of the Hungarian Scientific Research Fund (OTKA K108333) and by the European Union and the State of Hungary, co-financed by the European Social Fund in the framework of TÁMOP4.2.4.A/ 2-11/1-2012-0001 'National Excellence Program' under the project number: A2-SZJ-TOK-13-0061.

\section{References}

Aldwinckle H.S. (1974): Field susceptibility of 51 cultivars to scab and apple powdery mildew, Plant Dis. Rep. 58: 625-629.

Alston F.H. (1983): Progress in transferring mildew (Podosphaera leucotricha) resistance from Malus species to cultivated apple, IOBC/WPRS Bulletin 6 (4): 87-95.

Andrews J.H. (1990): Biological control in the phyllosphere realistic goal or false hope, Can. J. Plant Pathol. 12: 300-307.

Andrews J.H. (1992): Biological control in the phyllosphere, Annu. Rev. Phytopathol. 30: 603-635.

Anonymous (2000): IFOAM Basic Standards for Organic Production and Processing, Tholey-Theley Press, New York, USA.

Berrie A.M., Xu X-M. (2003): Managing apple scab and powdery mildew using Adem ${ }^{\mathrm{TM}}$, Int. J. Pest Manage. 49: 243-250.

Bosshard E. (1992): The effect of Ivy (Hedera helix) leaf extract against apple scab and mildew, Acta Phytopathol. Entomol. Hung. 27: 135-140.

Bower K.N., Berkette L.P., Constante J.F. (1995): Nontarget effects of a fungicide spray program on phytophagous and predacious mite populations in a scab-resistant apple orchard, Environ. Entomol. 24: 423-430.

Caffier V., Laurens F. (2005): Breakdown of Pl-2, a major gene of resistance to apple powdery mildew, in a French experimental orchard, Plant Pathol. 54: 116-124.

Caffier V., Parisi L. (2007): Development of apple powdery mildew on sources of resistance to Podosphaera leucotricha, exposed to an inoculum virulent against the major resistance gene Pl-2, Plant Breeding 126: 319-322.
Cross J.V., Berrie A.M. (1995): Field evaluation of a tunnel sprayer and effects of spray volume at constant drop size on spray deposits and efficacy of disease control on apple, Ann. Appl. Biol. 127: 521-532.

Csorba Z. (1962): Az almafa-lisztharmat [Apple Powdery Mildew], Mezőgazdasági Kiadó, Budapest, Hungary.

Evans K.M., James C.M. (2003): Identification of SCAR markers linked to $\mathrm{Pl}-\mathrm{w}$ mildew resistance in apple, Theor. Appl. Genet. 106: 1178-1183.

Fernandez D.E., Beers E.H., Brunner J.F., Doerr M.D., Dun J.E. (2006): Horticultural mineral oil applications for apple powdery mildew and codling moth, Cydia pomonella (L.), Crop Prot. 25: 585-591.

Fischer C., Fischer M. (1999): Evaluation of Malus species and cultivars at the Fruit Genebank Dresden-Pillnitz and its use for apple resistance breeding, Genet. Resour. Crop Evol. 46: 235241.

Grove G.G., Boal R.J. (1996): Horticultural oil sprays for the control of powdery mildew of apple at Quincy, WA, 1995, Fung. Nemat. Tests 51: 35 .

Hickey K.D., Yoder K.S. (1990): Powdery mildew, in: Jones A.L., Aldwinckle H. S. (Eds.), Compendium of Apple and Pear Diseases, APS, St. Paul, Minnesota, USA, pp. 9-10.

Holb I.J. (2005): Effect of pruning on disease incidence of apple scab and powdery mildew in integrated and organic apple production. Internat. J. Hortic. Sci. 11 (1): 57-61.

Holb I.J. (2013): Apple powdery mildew caused by Podosphaera leucotricha: some aspects of biology. International Journal of Horticultural Science, 19: (3-4):

James C.M., Clarke J.B., Evans K.M. (2005): Identification of molecular markers linked to the mildew resistance gene $\mathrm{Pl}-\mathrm{d}$ in apple, Theor. Appl. Genet. 110: 175-181.

Knight R.L., Alston F.H. (1968): Sources of field immunity to mildew (Podosphaera leucotricha) in apple, Can. J. Genet. Cytol. 10: 294-298.

Korban S.S., Dayton D.F. (1983): Evaluation of Malus germplasm for resistance to powdery mildew, HortScience 18: 219-220.

Laurens F. (1999) Review of the current apple breeding programmes in the world: objective for scion cultivar improvement, Acta Hort. 484: $162-170$

Lesemann S.S., Schimpke S., Dunemann F., Deising H.B. (2006): Mitochondrial heteroplasmy for the cytochrome $b$ gene controls the level of strobilurin resistance in the apple powdery mildew fungus Podosphaera leucotricha (Ell. \& Ev.) ES Salmon, J. Plant Dis. Prot. 113: 259-266.

Lespinasse Y. (1983): Am'elioration du pommier pour la rèsistance a l'oïdium (Podosphaera leucotricha) - premiers resultants concernant la virulence du champignon, IOBC/WPRS Bulletin 6 (4): 96-110.

Lespinasse Y. (1989): Three genes, resistance mechanisms, present work and prospects, IOBC/WPRS Bulletin, 12: 100-115.

Northover J., Schneider K.E. (1993) Activity of plant oils on diseases caused by Podosphaera leucotricha, Venturia inaequalis, and Albugo occidentialis, Plant Dis. 77: 152-157.

Northover J., Schneider K.E. (1996) Physical modes of action of petroleum and plant oils on powdery and downy mildews of grapevines, Plant Dis. 80: 544-550. 
Norton R.A. (1981): Field susceptibility of apple cultivars to scab, Venturia inaequalis, and powdery mildew, Podosphaera leucotricha in a cool, humid climate, Fruit Varieties J. 32: 2-5.

Palti J. (1981): Cultural Practices and Infectious Crop Diseases. Springer-Verlag, New York, USA.

Reuveni M., Oppenheim D., Reuveni R. (1998): Integrated control of powdery mildew on apple trees by foliar sprays of monopotassium phosphate fertilizer and sterol inhibiting fungicides, Crop Prot. 17: 563-568.

Reuveni M. (2000): Efficacy of trifloxystrobin (Flint), a new strobilurin fungicide, in controlling powdery mildews on apple, mango and nectarine, and rust on prune tree, Crop Prot. 19: 335341.

Scheer van der H.A.Th. (1989): Susceptibility of apple cultivars and selections to scab and powdery mildew in The Netherlands, IOBC/WPRS Bulletin 12 (6): 205-211.

Schmidt H. (1994): Progress in combining mildew resistance from Malus robusta and Malus zumi with fruit quality. [In: Schmidt H., Kellerhals M. (Eds.), Progress in Temperate Fruit Breeding] Kluwer Academic Publishers, Dordrecht, The Netherlands, pp. 3-6.

Sholberg P.L., Haag P. (1994) Control of apple powdery mildew (Podosphaera leucotricha) in British-Columbia by demethylationinhibiting fungicides, Can. Plant Dis. Surv. 74: 5-11.

Sholberg P.L., Lane W.D., Haag P., Bedford K., Lashuk L. (2001) A novel technique for evaluation of apple (Malus x domestica Borkh.) cultivars for susceptibility to powdery mildew, Can. J. Plant Sci. 81: 289-296.
Spotts R.A., Cervantes L.A. (1986) Effects of fungicides that inhibit ergosterol biosynthesis on apple powdery mildew control, yield, and fruit growth factors, Plant Dis. 70: 305-306.

SztejnbergA., Galper S., Mazar S., Lisker N. (1989) Ampelomyces quisqualis for biological and integrated control of powdery mildew in Israel, J. Phytopathol. 124: 285-295.

Washington W.S., Villalta O.N., Ingram J., Bardon D. (1998) Susceptibility of apple cultivars to apple scab and powdery mildew in Victoria, Australia, Austr. J. Experim. Agric. 38: 625-629.

White A.G., Bus V.G. (1999) Breeding commercial apple cultivars in New Zealand with resistances to pests and diseases, Acta Hort. 484: 157-161.

Xu X-M. (1999) Modelling and forecasting the epidemics of apple powdery mildew (Podosphaera leucotricha), Plant Pathol. 48: 462471.

Xu X-M., Madden L.V. (2002) Incidence and density relationships of powdery mildew on apple, Phytopathology 92: 1005-1014.

Yoder K.S. (2000) Effect of powdery mildew on apple yield and economic benefits of its management in Virginia, Plant Dis. 84: 1171-1176.

Yoder K.S., Hickey K.D. (1983) Control of apple powdery mildew in the mid-Atlantic region, Plant Dis. 67: 245-248.

Yoder K.S., Hickey K.D. (1995) Apple powdery mildew, in: MidAtlantic Orchard Monitoring Guide. pp. 238.

Yoder K.S., Cochran A.E.I., Royston Jr., W.S., Kilmer S.W. (2002) Comparison of biocontrol, oil-related and conventional fungicides on Idared apple, 2001, Fung. Nemat. Tests 57: PF31. 